\title{
Article \\ High Soil Phosphorus Application Significantly Increased Grain Yield, Phosphorus Content but Not Zinc Content of Cowpea Grains
}

\author{
Saba B. Mohammed ${ }^{1,2}, *$ (D), Daniel K. Dzidzienyo ${ }^{2}$, Adama Yahaya ${ }^{3}$, Muhammad L. Umar ${ }^{1}$, \\ Mohammad F. Ishiyaku ${ }^{1}$, Pangirayi B. Tongoona ${ }^{2}$ and Vernon Gracen ${ }^{2,4}$ \\ 1 Institute for Agricultural Research, Ahmadu Bello University, Zaria 800001, Nigeria; \\ mahammadlawan@yahoo.com (M.L.U.); mffaguji@hotmail.com (M.F.I.) \\ 2 West Africa Centre for Crop Improvement, University of Ghana, Accra 233, Ghana; \\ ddzidzienyo@wacci.ug.edu.gh (D.K.D.); ptongoona@wacci.ug.edu.gh (P.B.T.); vg45@cornell.edu (V.G.) \\ 3 Department of Botany, Ahmadu Bello University, Zaria 800001, Nigeria; yadamcy@yahoo.com \\ 4 Department of Plant Breeding and Genetics, Cornell University, Ithaca, NY 31328, USA \\ * Correspondence: bsmohammed@abu.edu.ng; Tel.: +234-806-929-9881
}

Citation: Mohammed, S.B.; Dzidzienyo, D.K.; Yahaya, A.; Umar, M.L.; Ishiyaku, M.F.; Tongoona, P.B.; Gracen, V. High Soil Phosphorus Application Significantly Increased Grain Yield, Phosphorus Content but Not Zinc Content of Cowpea Grains. Agronomy 2021, 11, 802.

https://doi.org/10.3390/ agronomy11040802

Received: 9 February 2021

Accepted: 14 April 2021

Published: 19 April 2021

Publisher's Note: MDPI stays neutral with regard to jurisdictional claims in published maps and institutional affiliations.

Copyright: (c) 2021 by the authors. Licensee MDPI, Basel, Switzerland. This article is an open access article distributed under the terms and conditions of the Creative Commons Attribution (CC BY) license (https:// creativecommons.org/licenses/by/ $4.0 /)$.

\begin{abstract}
To ameliorate the impact of soil phosphorus (P) deficiency on cowpea, the use of P-based fertilizers is recommended. Plant zinc $(\mathrm{Zn})$ is an essential nutrient required by plants in a wide range of processes, such as growth hormone production and metabolism. However, a negative association between plant $\mathrm{Zn}$ content and high $\mathrm{P}$ application has been reported in some crops. There are few reports about soil $\mathrm{P}$ application and plant $\mathrm{Zn}$ content relationship on cowpea. Thus, this study investigated the response of cowpeas to three $P$ rates in the screenhouse $(0,1.5$, and $30 \mathrm{mg} \mathrm{P} / \mathrm{kg})$ and field $\left(0,10\right.$, and $60 \mathrm{~kg} \mathrm{P}_{2} \mathrm{O}_{5} / \mathrm{ha}$ ) and their effects on plant $\mathrm{P}$ and $\mathrm{Zn}$ content, biomass, and grain yield. In the screenhouse, shoot and root dry weights, and shoot $\mathrm{P}$ and $\mathrm{Zn}$ content were measured. Shoot dry weight, grain yield, grain $\mathrm{P}$, and $\mathrm{Zn}$ contents were determined from field plants. Higher rates of $P$ led to increased shoot biomass and grain yield of the field experiment but were not associated with a significant change in shoot or grain $\mathrm{Zn}$ content. There was not a significant correlation between grain yield and $\mathrm{Zn}$ content in high soil $\mathrm{P}(p<0.05)$. The effect of higher $\mathrm{P}$ application on reduced plant $\mathrm{Zn}$ contents may be genotype-dependent and could be circumvented if genotypes with high $\mathrm{Zn}$ content under high soil $\mathrm{P}$ are identified.
\end{abstract}

Keywords: cowpea; fertilizer; grain phosphorus; grain yield; grain zinc; phosphorus; shoot phosphorus; shoot zinc; zinc content

\section{Introduction}

Zinc $(\mathrm{Zn})$ is among the seven most limiting micronutrients in human diets, as over two-thirds of the global diets are deficient in one or more of iron (Fe), zinc, copper, calcium, magnesium, iodine, and selenium [1,2]. $\mathrm{Zn}$ is especially needed by pregnant women and children, especially because of its critical roles in pregnancy, enhanced protection from infection, and maintenance of immune system functions. Its deficiency can lead to complications in childbirth, low birth weight, poor growth of children, and reduced tolerance to infectious diseases [3-5]. $\mathrm{Zn}$ is also an important factor in the prevention and treatment of common diseases such as common cold, malaria, diarrhea, and respiratory infections $[4,5]$.

Cowpea is a pulse crop providing food, nutrition, and cash for its value-chain actors across sub-Saharan Africa (SSA) and beyond [6,7]. Every part of the crop, including leaves, green pods, and grains, are used by humans in making different dishes and its fodder is used for livestock feed $[8,9]$. Due to its rich protein content, the crop serves as an important supplement for the carbohydrate-rich cereals $[9,10]$. Cowpea is a strategically important 
crop capable of providing millions of people with nutritional security owing to its rich nutritional value, especially high protein, Fe, and $\mathrm{Zn}$. This contributes to its increasing popularity [11]. Cowpeas are cultivated by smallholder farmers on soils with low available plant phosphorus (P) with minimal to no P application [12-14].

Cereals are the most important source of calories globally but are deficient in $\mathrm{Zn}$ and Fe due to the high content of phytic acids in grains that decrease the bioavailability of $\mathrm{Zn}$. Therefore, Zn deficiency is likely to be high in areas where cereals are the dominant food source [4,15]. Legumes, being rich in important micronutrients like Fe and Zn, serve as good complimentary food to micronutrient-deficient cereals $[11,16]$. P is stored in most legumes including cowpea as phytic acid, which is known to limit the bioavailability of $\mathrm{Zn}$ [16-18].

Increasing the bioavailability of micronutrients in human diets has become a global priority, particularly for Fe and $\mathrm{Zn}$ in developing countries, where many people depend on plant-based food products for nutrition $[11,19,20]$. Enhancing the bioavailability of micronutrients in food could be achieved through improved agronomic practices such as optimum application of fertilizers with micronutrients, and genetic improvement of elite crop varieties [1,19]. Other ways to remedy micronutrients deficiency in food crops include biofortification, diversity of diet, mineral supplementation, and food fortification $[1,15,21,22]$.

In SSA, micronutrient deficiency is not only found in edible parts of plants, like grains, but also in most soils of growing areas of major crops, including cowpeas. Micronutrient deficiency of grains is further worsened because most farmers do not apply micronutrients such as $\mathrm{Zn}$ to crop plants, even when the application of $\mathrm{Zn}$ to cowpea is known to increase both grain yield and $\mathrm{Zn}$ content [20]. The low P of soils further leads to low productivity of the crop $[7,23,24]$.

Application of fertilizers supplying major nutrients like nitrogen-phosphorus-potassium (NPK), with little or no consideration of micronutrient requirements, may lead to a reduced amount of micronutrients in the edible tissues that serve as food for people [18], since the micronutrient content of grains depends largely on the supply from soil nutrient pool and micronutrients-containing fertilizers $[1,18]$. Two complementary approaches have been recommended to achieve high cowpea yield on soils with low available P. First is the use of improved agronomic approaches such as application of phosphate fertilizers, and second is the development of elite varieties with high P use efficiency [25-27]. Varieties with improved $\mathrm{P}$ efficiencies use different mechanisms, including increased solubilization and mobilization of soil $\mathrm{P}$, improved root architecture traits, and increased ability to acquire $P$ and accumulate it in edible tissues [27-30].

Loneragan and Webb [31] reported that there is confusing literature on plant $\mathrm{P}-\mathrm{Zn}$ interactions for crop plants and noted that the subject of plant $\mathrm{P}-\mathrm{Zn}$ interactions remains complex, involving many phenomena in both soils and plants, such as observations that $\mathrm{P}$ applications can decrease, or not decrease, $\mathrm{Zn}$ content in plant grains and shoots. The application of phosphate fertilizer is required for increased productivity of cowpea in areas with low soil available P. However, its influence on micronutrient availability on the grains and leaves has not been adequately investigated $[16,32,33]$. The application of $\mathrm{P}$, especially at a high rate, may be counterproductive, if $\mathrm{P}$ application negatively affects $\mathrm{Zn}$ availability, as has been found in some cereals $[15,18,22,34]$. Thus, it is important to investigate the influence of $P$ fertilizer applications on cowpea's growth (root and shoot biomass), grain yield, and the potential relationship between $\mathrm{P}$ application in the growth medium and $\mathrm{Zn}$ content in shoot and grain at varying levels of $\mathrm{P}$ concentrations of the growth environment.

\section{Materials and Methods}

\subsection{Plant Materials}

A total of thirty elite cowpea genotypes from four different breeding programs in West Africa (Burkina Faso, Ghana, and Nigeria) and the USA were used. Twenty were parents for recombinant inbred line populations previously studied for mapping of important biotic and abiotic stresses [35-37]. The genotypes are presented in Supplementary Table S1. 


\subsection{Description of the Experiments}

Two experiments were conducted: one in the screenhouse and the other under the field environment. In the screenhouse experiment, a river-sand was collected from the bank of a local stream "Rafin Kudingi" at the Ahmadu Bello University Nigeria $\left(11^{\circ} 09^{\prime} 49.6^{\prime \prime} \mathrm{N}\right.$ $7^{\circ} 37^{\prime} 13.8^{\prime \prime} \mathrm{E}$ ) and was acid-washed with $1 \% \mathrm{HCl}$. The acid-washed sand used had very low P $(3.70 \mathrm{mg} / \mathrm{kg}), \mathrm{N}(0.11 \mathrm{~g} / \mathrm{kg})$, and $\mathrm{K}(0.08 \mathrm{cmol} / \mathrm{kg})$ and organic carbon $(0.24 \mathrm{~g} / \mathrm{kg}$ of soil contents), determined at the Department of Soil Science, Ahmadu Bello University Nigeria, and this appropriately mimics major nutrient-deficient soil [38]. A Hoagland nutrient solution with three different concentrations of $\mathrm{P}(0,1.5$, and $30 \mathrm{mg} \mathrm{P} / \mathrm{kg}$ of soil) as described in a previous study on cowpea [39] was used to water the plants during the experiment. The screenhouse experiment used a randomized complete block design in five replications. Cowpea seeds were sown and thinned to one plant per pot at 10 days after sowing (DAS). The pots were watered with the dilute nutrient solution with graduated beakers as follows: $300 \mathrm{~mL}$ per pot at planting, and subsequently $300 \mathrm{~mL}$ was applied at $3,6,9,16,23,30,37,44$, and 51 DAS for each of the P treatments $(0,1.5$, and $30 \mathrm{mg} \mathrm{P} / \mathrm{kg}$ soil). Reverse osmosis (RO) was used to water the pots periodically to prevent wilting and prevent the accumulation of salts in the soil. Spraying of insecticide (Karate $50 \mathrm{~g} / \mathrm{L}$ lambda-cyhalothrin, Syngenta Crop Protection AG, Basel, Switzerland) was used to protect the plants against insect pests. Data on plant height $(\mathrm{cm})$, shoot dry weight $(\mathrm{g})$, root dry weight (g), total plant dry weight (g) (shoot and root dry weights), shoot $\mathrm{P}$, root $\mathrm{P}$, and shoot and root $\mathrm{Zn}$ content were collected from the screenhouse plants. Plant growth continued until 55 days, at which time the screenhouse experiment was terminated.

A field experiment, comprising the same set of genotypes used in the screenhouse experiment described above, was conducted in a low P field (4.2 $\mathrm{mg} \mathrm{P} / \mathrm{kg}$-Bray-I method) at the Institute for Agricultural Research farm $\left(11^{\circ} 10^{\prime} 31.7^{\prime \prime} \mathrm{N} 7^{\circ} 36^{\prime} 43.9^{\prime \prime} \mathrm{E}\right)$, Nigeria. The field used has been left uncultivated for several years and had low $\mathrm{P}(4.2 \mathrm{mg} / \mathrm{kg})$, $\mathrm{N}(0.13 \mathrm{~g} / \mathrm{kg})$, and $\mathrm{K}(0.68 \mathrm{cmol} / \mathrm{kg})$ and organic carbon $(0.79 \mathrm{~g} / \mathrm{kg}$ of soil content $)$, as determined by the Department of Soil Science, Ahmadu Bello University, Nigeria. In the field, $\mathrm{P}$ was applied using a single super phosphate fertilizer (SSP $18 \% \mathrm{P}_{2} \mathrm{O}_{5}, 11 \%$ Sulphur, $18 \% \mathrm{Ca}$, and $4 \%$ moisture (TAK-AGRO, Kaduna, Nigeria)) at the rate of 0,10 , and $60 \mathrm{~kg} \mathrm{P}_{2} \mathrm{O}_{5} \mathrm{ha}^{-1}$ based on previous phosphate recommendations for cowpea [7,27]. The field experiment was a factorial arrangement (with two factors, namely: 30 cowpea genotypes and three $\mathrm{P}$ levels) in a randomized complete block design laid out in two replications. Plots were one row of $2 \mathrm{~m}$ each with a $1 \mathrm{~m}$ unplanted walkway between plots, giving a pot size of $1.5 \mathrm{~m}^{2}$ with an intra- and inter-row spacing of 0.20 and $0.75 \mathrm{~m}$, respectively. All the field plots received $30 \mathrm{~kg} / \mathrm{ha} \mathrm{N}\left(46 \% \mathrm{~N}\right.$, Urea) and $\mathrm{K}\left(30 \% \mathrm{~K}_{2} \mathrm{O}\right.$, Muriate of Potash) to avoid any confounding effects of $\mathrm{N}$ and $\mathrm{K}$ deficiency on the plants. All the single fertilizers were applied as dual banding by placing them below the soil surface five days after sowing. Plants were protected against insect pests by spraying insecticide (Karate $50 \mathrm{~g} / \mathrm{L}$ lambdacyhalothrin, Syngenta Crop Protection AG, Basel, Switzerland). Data collected from the field experiment are plant height $(\mathrm{cm})$, shoot dry weight $(\mathrm{g})$, root dry weight $(\mathrm{g})$, total plant dry weight (g) (shoot and root dry weights), grain yield ( $\mathrm{kg} / \mathrm{ha}$ ), P concentration, and $\mathrm{Zn}$ content of the grains, shoot, and root samples. See Table 1 for the list and abbreviation of the traits measured. 
Table 1. List of trait names with their abbreviation and definitions.

\begin{tabular}{|c|c|}
\hline Traits & Definition and Abbreviations \\
\hline Grain yield, kg/ha & $\begin{array}{l}\text { Grain yield in kg per hectare from the low, medium, and high } \\
\text { phosphorus treatments (yield.LP, yield.MP, and yield.HP) }\end{array}$ \\
\hline $\begin{array}{l}\text { Grain phosphorus } \\
\text { concentration, } \mathrm{mg} / \mathrm{kg}\end{array}$ & $\begin{array}{l}\text { Phosphorus concentration determined from grain samples } \\
\text { from the low, medium, and high phosphorus treatments } \\
\text { (grainP.LP, grainP.MP, and grainP.HP) }\end{array}$ \\
\hline Grain zinc content, ppm & $\begin{array}{l}\text { The zinc content of grain samples from the low, medium, and } \\
\text { high phosphorus treatments (grainZn.LP, grainZn.MP, and } \\
\text { grainZn.HP) }\end{array}$ \\
\hline Plant height, $\mathrm{cm}$ & $\begin{array}{l}\text { The height of the plant measured in centimeters from the soil } \\
\text { surface to the base of the top leaf on the main stem (average } \\
\text { per genotype) (pht.LP, pht.MP, and pht.HP) }\end{array}$ \\
\hline Root dry weight, gram & $\begin{array}{l}\text { Weight of dry root, per plot of low, medium, and high } \\
\text { phosphorus treatments (rdwt.LP, rdwt.MP, and rdwt.HP) }\end{array}$ \\
\hline $\begin{array}{l}\text { Root phosphorus concentration, } \\
\mathrm{mg} / \mathrm{kg}\end{array}$ & $\begin{array}{l}\text { Phosphorus concentration determined from root samples } \\
\text { from the low, medium, and high phosphorus treatments } \\
\text { (rootP.LP, rootP.MP, and rootP.HP) }\end{array}$ \\
\hline Root zinc content, ppm & $\begin{array}{l}\text { The zinc content of root samples from the low, medium, and } \\
\text { high phosphorus treatments (rootZn.LP, rootZn.MP, and } \\
\text { rootZn.HP) }\end{array}$ \\
\hline Shoot dry weight, gram & $\begin{array}{l}\text { Weight of dry shoot, per plot of low, medium, and high } \\
\text { phosphorus treatments (sdwt.LP, sdwt.MP, and sdwt.HP) }\end{array}$ \\
\hline $\begin{array}{l}\text { Shoot phosphorus } \\
\text { concentration, } \mathrm{mg} / \mathrm{kg}\end{array}$ & $\begin{array}{l}\text { Phosphorus concentration determined from shoot samples } \\
\text { from the low, medium, and high phosphorus treatments } \\
\text { (shootP.LP, shootP.MP, and shootP.HP) }\end{array}$ \\
\hline Shoot zinc content, ppm & $\begin{array}{l}\text { The zinc content of shoot samples from the low, medium, and } \\
\text { high phosphorus treatments (shootZn.LP, shootZn.MP, and } \\
\text { shootZn.HP) }\end{array}$ \\
\hline Soil phosphorus content, $\mathrm{mg} / \mathrm{kg}$ & $\begin{array}{l}\text { Plant available phosphorus from the low, medium, and high } \\
\text { phosphorus plots (soilP.LP, soilP.MP, and soil.P.HP), } \\
\text { determined using the Bray-I method }\end{array}$ \\
\hline
\end{tabular}

\subsection{Determination of Phosphorus Concentration and Zinc Content from Plant Tissues}

Samples of shoots and grains were taken from the screenhouse (only shoot samples) and field experiments and analyzed for P concentration and $\mathrm{Zn}$ content. Grain samples were ground using mortar and pestle, whereas an electric blender was used to mill shoot samples. From each sample, $0.2 \mathrm{~g}$ was then weighed using an electric balance (Scout ${ }^{\mathrm{tm}}$ Pro SPU202, Ohaus Corporation, Parsippany, NJ, USA) and digested with $30 \mathrm{~mL}$ mixed acids (containing $26 \mathrm{~mL}$ nitric acid, $3.2 \mathrm{~mL}$ perchloric, and $0.8 \mathrm{~mL}$ sulfuric acids), then placed on a digestion block set at $230-300{ }^{\circ} \mathrm{C}$. The digest was then transferred into a $50 \mathrm{~mL}$ volumetric flask and brought up to $50 \mathrm{~mL}$ with distilled water. Thereafter, $5 \mathrm{~mL}$ of the extract for each sample was pipetted into a $25 \mathrm{~mL}$ volumetric flask and $5 \mathrm{~mL}$ of a color developing agent made up of $50 \mathrm{~g}$ ammonium molybdate dissolved in $500 \mathrm{~mL}$ distilled water, $2.5 \mathrm{~g}$ ammonium metavanadate dissolved in $500 \mathrm{~mL}$ distilled water, and $350 \mathrm{~mL}$ nitric acid in $1000 \mathrm{~mL}$ of distilled water, which were all mixed and made up to $2.5 \mathrm{~L}$ with distilled water. To determine $\mathrm{P}$ concentration, absorbent readings were taken using a Spectrophotometer (Helios Gamma UVG 875005, Spectronic Unicam, Caerphilly, UK) at a wavelength of $460 \mathrm{~nm}$. The Zn content was determined using an atomic absorption spectrometer (AA280FS, Agilent Technologies, Santa Clara, CA, USA). Zn standard solutions were made using the $1000 \mu \mathrm{g} / \mathrm{mL}$ Zn Standard $(1000 \mu \mathrm{g} / \mathrm{mL}$ SpectraScan, Teknolab AS, Verkstedveien, $\mathrm{Ski}$, Norway). The P concentration was determined in $\mathrm{mg} / \mathrm{kg}$, whereas the $\mathrm{Zn}$ was computed in parts per million (ppm). The formula for Zn content and P concentration computations are presented in Supplementary Table S2. 


\subsection{Statistical Analyses}

\subsubsection{Descriptive Analysis}

Data from both the screenhouse and field experiments, including shoot parameters, yield (shoot and grain), $\mathrm{P}$ concentrations, and $\mathrm{Zn}$ content, were analyzed using the linear mixed effect model to generate the best linear unbiased estimator (BLUE) using the lme4 package in R. The BLUE outputs were used to visualize the phenotypic distribution of the measured traits with box plots using the ggplot 2 package in $\mathrm{R}$ ( $\mathrm{R}$ Core Team). The relative difference (\%) in performance between the high $\mathrm{P}$ and low $\mathrm{P}$ (control) were computed (Supplementary Table S2).

\subsubsection{Relationships among Yield, Phosphorus, and Zinc Content}

The relationship among yield (biomass and grain), plant $\mathrm{P}$, and $\mathrm{Zn}$ content phenotypes at the different soil $\mathrm{P}$ rate were investigated with the Pearson-product moment correlation and correlation matrices were visualized with the corrplot package in $R$ (R Core Team).

\subsubsection{Interaction of the Genotype Main Effect Plus Genotype by Environment of the Genotypes}

The means of grain yield and grain $\mathrm{Zn}$ content were used to run a site regression analysis, also called genotype main effect plus genotype-environment interaction (GGE) [40]. The GGE is a linear-bilinear model that removes the effect of the environment (here, the rates of soil P) and expresses the output as a function of the genotype effects and its interaction with the environment. This model was used since the P rates are the main source of variation concerning the contributions of the genotypes and the interaction of the genotypes $\times$ P rates. The varying soil P rates were taken as environments for the analysis to identify the mean performance and stability of the genotypes, determined by their location and proximity to the origin of the biplot [40]. The GGE biplot outputs were used to indicate discrimination of the environments (P rates), and the correlation coefficient between the environments. The model used for the GGE analysis is as below:

$$
Y_{i j}=\mu+e_{j}+\sum_{n=1}^{N} T_{n} \gamma_{i n} \delta_{j n}+\varepsilon_{i j}
$$

where $Y_{i j}$ is the grain yield/Zn content of the $i$-th genotype $(i=1, \ldots, 30)$ in the $j$-th $P$ rates $(j=1, \ldots, 3), \mu$ is the grand mean, $e_{j}$ is the $P$ rates' deviations from the grand mean, $T_{n}$ is the eigenvalue of the principal component (PC) analysis axis $n, \gamma_{\text {in }}$ and $\delta_{\text {in }}$ are the genotype and P rates' PC scores for axis $\mathrm{n}, \mathrm{N}$ is the number of $\mathrm{PC}$ retained in the model, and $\varepsilon_{\mathrm{ij}}$ is the error term.

\section{Results}

\subsection{Variable Soil Phosphorus Effect on Shoot Dry Matter and Content of Phosphorus and Zinc}

Phosphorus $(\mathrm{P})$ fertilization was positively associated with increased growth and performance of the plants for most of the measured traits under the screenhouse conditions where plants were grown on acid-washed river-sand soil supplemented with Hoagland nutrients solution with varying $P$ levels. The plant height, shoot dry weight, root dry weight, shoot to root ratio, and shoot $\mathrm{P}$ concentrations increased with increasing $\mathrm{P}$ supply, but the addition of $\mathrm{P}$ to the growth media did not result in increased shoot $\mathrm{Zn}$ content of the genotypes (Figure 1). The root $\mathrm{Zn}$ content of the MP and HP treatments were similar, though were higher than those of the LP treatment. A similar response was observed for the plants grown in the field with varying P supplied with the addition of SSP fertilizer, where plant height, shoot dry weight, root dry weight, total plant dry weight, grain yield, and $\mathrm{P}$ concentration of the grains increased as the $\mathrm{P}$ in the soil increased, except shoot $\mathrm{P}$, root $\mathrm{P}$, seed weight (g/100 seeds), root, and grain $\mathrm{Zn}$ contents (Figures 2 and 3, Supplementary Figure S1). There was a noticeable increase in shoot Zn content with the varying soil P rates among the genotypes, which were not significantly different between 
the $\mathrm{P}$ treatments (Figure 3). The increase in shoot growth with the addition of more $\mathrm{P}$ to the growth media indicates that the soils used were suboptimal in available $P$. The increase in growth parameters and performance indicators was maximum for many traits when the applied $\mathrm{P}$ was highest for most of the parameters measured, except for shoot $\mathrm{Zn}$ content in the screenhouse, and shoot $\mathrm{Zn}$, root $\mathrm{Zn}$, and grain $\mathrm{Zn}$ contents in the field experiments. It therefore means that high soil $P$ fertilization does not significantly result in reduced grain $Z n$ content. The highest level of $P$ fertilization did slightly, but not significantly, reduce shoot $\mathrm{Zn}$ content from the field results (Figure 3). The grain $\mathrm{Zn}$ content was relatively higher when $\mathrm{P}$ application was low and medium in the growth media compared with high P (Figure 3, see Supplementary Tables S3 and S4 for means of parameters assessed for all genotypes evaluated in the screenhouse and the field environments), though the differences were not significant as determined by the Tukey honestly significant difference test.
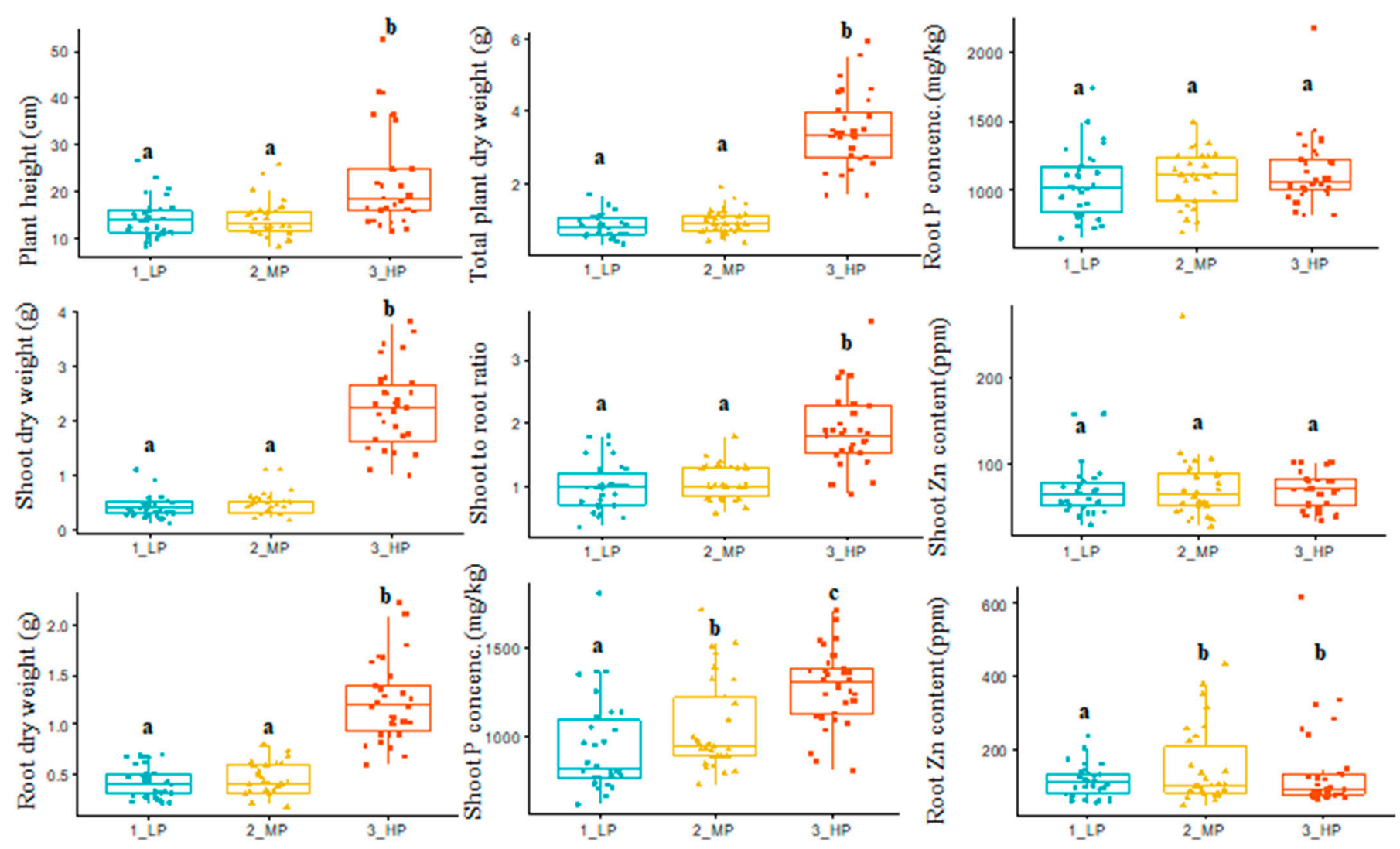

Figure 1. Phenotypic distribution of traits measured in the screenhouse under varying soil phosphorus levels. Box plot displays the median of each group bounded by the first and third quartile, where the $X$-axis is soil phosphorus concentrations. 1_LP = no-P application, 2_MP $=1.5 \mathrm{mg} \mathrm{P} \mathrm{kg}^{-1}$, and 3_HP $=30 \mathrm{mg} \mathrm{P} \mathrm{kg}^{-1}$ added to Hoagland nutrient solution used for watering the plants. Letters above each box plot denote similarity among groups as per Tukey's honestly significant difference comparison test $(\alpha \leq 0.05)$. Means with the same letter are not significantly different. 

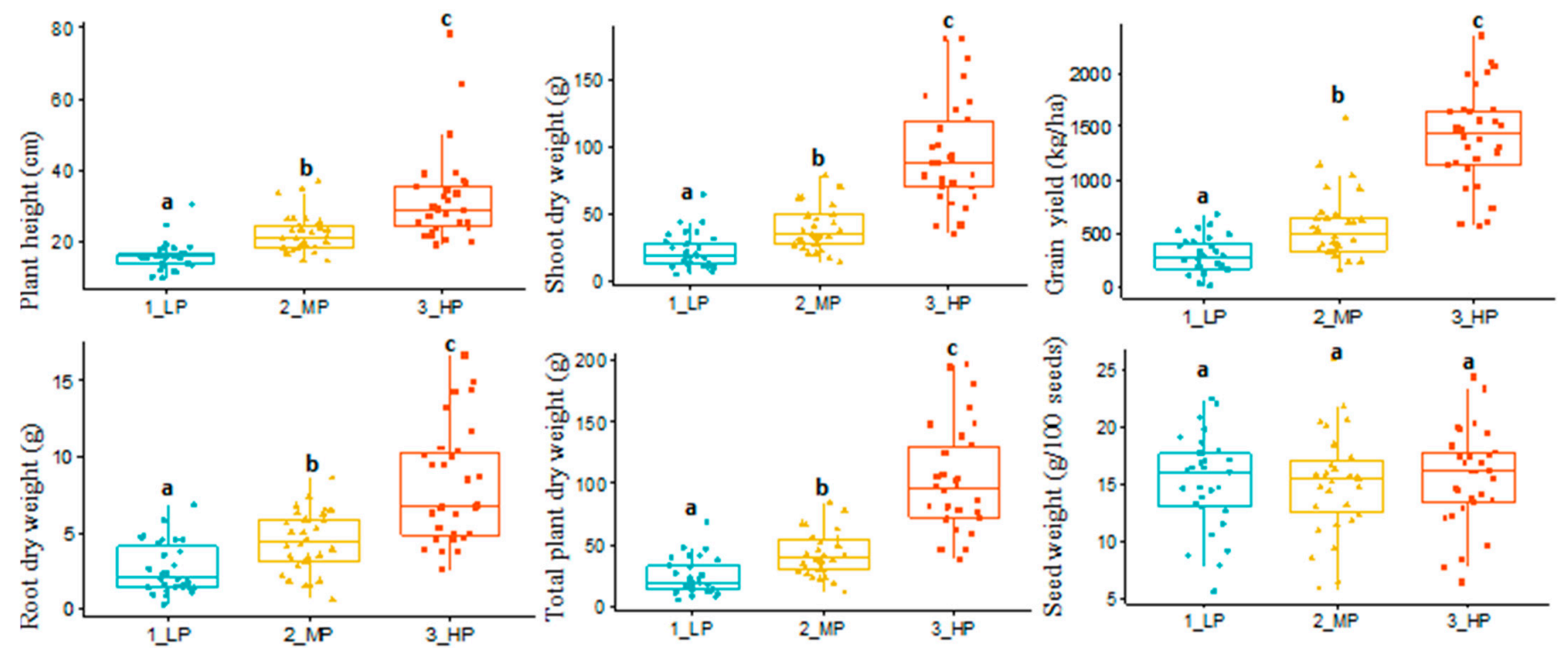

Figure 2. Phenotypic distribution of growth and yield parameters measured in the field under varying soil phosphorus levels. Box plot displays the median of each group bounded by the first and third quartile, where the $X$-axis is soil phosphorus concentrations, with 1_LP $=$ no-P application, 2_MP $=10 \mathrm{~kg} \mathrm{P}_{2} \mathrm{O}_{5} \mathrm{ha}^{-1}$, and 3_HP $=60 \mathrm{~kg} \mathrm{P}_{2} \mathrm{O}_{5} \mathrm{ha}^{-1}$. Letters above each box plot denote similarity among groups as per Tukey's honestly significant difference comparison test $(\alpha \leq 0.05)$. Means with the same letter are not significantly different.
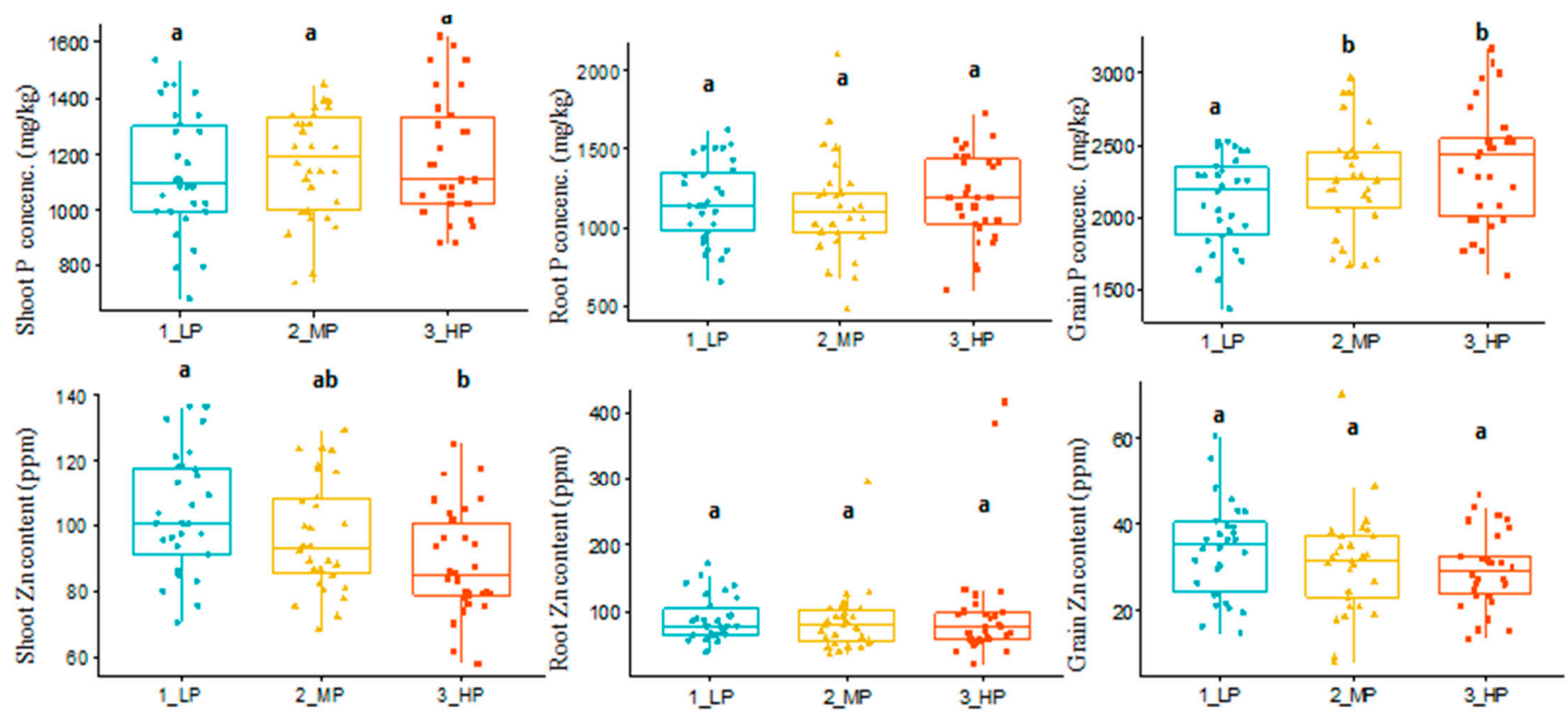

Figure 3. Phenotypic distribution of phosphorus $(\mathrm{P})$ and zinc $(\mathrm{Zn})$ contents of shoot, root, and grains from the field environment under varying soil phosphorus levels. Box plot displays the median of each group bounded by the first and third quartile, where the $X$-axis is soil phosphorus concentrations, with $1 \_L P=$ no-P application, $2 \_M P=10 \mathrm{~kg} \mathrm{P}_{2} \mathrm{O}_{5} \mathrm{ha}^{-1}$, and 3_HP $=60 \mathrm{~kg} \mathrm{P}_{2} \mathrm{O}_{5} \mathrm{ha}^{-1}$. Letters above each box plot denote similarity among groups as per Tukey's honestly significant difference comparison test $(\alpha \leq 0.05)$. Means with the same letter are not significantly different.

The relative increase in plant height, shoot dry weight, shoot $\mathrm{P}$ concentration, and shoot $\mathrm{Zn}$ content in high $\mathrm{P}(\mathrm{HP})$ over the low $\mathrm{P}$ (control) was $34.6 \%, 81.8 \%, 26.1 \%$, and $-3.51 \%$ respectively, in the screenhouse (Table 2), where the Zn content in the shoot at the HP (68.3 ppm) was slightly lower than the control (70.7 ppm), corresponding to $-3.5 \%$ relative reduction in $\mathrm{Zn}$ content of HP plants compared to the LP. The results for the field evaluation followed a comparable pattern with the screenhouse in the relative difference 
in $\mathrm{Zn}$ content of HP relative to other $\mathrm{P}$ treatments. An increase in grain yield and grain $\mathrm{P}$ followed a linear pattern with increasing $\mathrm{P}$ fertilizer to the soil, while $\mathrm{Zn}$ content was higher in plants evaluated under low and medium soil $\mathrm{P}$ vis-à-vis the high $\mathrm{P}$, which had a reduction of $17.1 \%$ in the Zn content of the HP over the LP (Table 2).

Table 2. Relative difference (RD) in performance of high phosphorus treatment relative to low phosphorus on some traits measured in the screenhouse and field conditions.

\begin{tabular}{|c|c|c|c|c|c|c|c|c|c|c|}
\hline \multicolumn{5}{|c|}{ Screenhouse } & \multicolumn{6}{|c|}{ Field } \\
\hline $\begin{array}{l}\text { Phosphorus } \\
\text { Levels }\end{array}$ & $\begin{array}{l}\text { Pht } \\
\text { (cm) }\end{array}$ & $\begin{array}{c}\text { Sdwt } \\
(\mathrm{g})\end{array}$ & $\begin{array}{l}\text { ShootP } \\
\text { (mg/kg) }\end{array}$ & $\begin{array}{c}\text { ShootZn } \\
\text { (ppm) }\end{array}$ & $\begin{array}{c}\text { Sdwt } \\
(\mathrm{g})\end{array}$ & $\begin{array}{l}\text { ShootP } \\
\text { (mg/kg) }\end{array}$ & $\begin{array}{c}\text { ShootZn } \\
\text { (ppm) }\end{array}$ & $\begin{array}{l}\text { Yield } \\
\text { (kg/ha) }\end{array}$ & $\begin{array}{l}\text { GrainP } \\
(\mathrm{mg} / \mathrm{kg})\end{array}$ & $\begin{array}{c}\text { GrainZn } \\
\text { (ppm) }\end{array}$ \\
\hline LP & 14.5 & 0.4 & 942.4 & 70.7 & 20.6 & 1132.4 & 103.9 & 294.1 & 2106.8 & 34.3 \\
\hline MP & 14.3 & 0.5 & 1054.1 & 73.4 & 38.9 & 1162.9 & 96.8 & 558.9 & 2286.4 & 31.5 \\
\hline $\mathrm{HP}$ & 22.2 & 2.2 & 1275.9 & 68.3 & 94.5 & 1183.7 & 88.7 & 1406.6 & 2368.2 & 29.3 \\
\hline $\mathrm{RD}(\%)$ & 34.6 & 81.8 & 26.1 & -3.5 & 78.2 & 4.3 & -17.1 & 79.1 & 11.0 & -17.1 \\
\hline
\end{tabular}

$\mathrm{LP}=$ low phosphorus (no-P application), $\mathrm{MP}=$ medium phosphorus $\left(1.5 \mathrm{mg} \mathrm{P} \mathrm{kg}^{-1}\right)$, and $\mathrm{HP}=$ high phosphorus $\left(30 \mathrm{mg} \mathrm{P} \mathrm{kg}^{-1}\right)$ for river-sand in the screenhouse, and $\mathrm{MP}=10 \mathrm{~kg} \mathrm{P}_{2} \mathrm{O}_{5} \mathrm{ha}^{-1}$ and High $\mathrm{P}=60 \mathrm{~kg} \mathrm{P}_{2} \mathrm{O}_{5} \mathrm{ha}^{-1}$ for field evaluation, where Pht = plant height $(\mathrm{cm})$ at maturity, Sdwt = shoot dry weight $(\mathrm{g}), \mathrm{P}=$ phosphorus concentration, $\mathrm{Zn}=$ zinc content, and $\mathrm{RD}=$ relative difference $(\%)$.

\subsection{Phenotypic Association between Yield Components and Zinc Content in Cowpea}

The relationships between several growth parameters and $\mathrm{Zn}$ content both in the screenhouse and field trials were not significant $(r=0.1-0.2)$ (Figures 4 and 5, Supplementary Tables S5 and S6). The shoot dry weight versus shoot $\mathrm{Zn}$ content at HP treatment had a weak negative correlation $(r=-0.1)$, while grain yield and grain $\mathrm{Zn}$ content at HP $(\mathrm{r}=0.1)$ showed a weak positively significant relationship from field evaluation (Figure 5), indicating that high yield and $\mathrm{Zn}$ content can be combined in some genotypes since there is no strong association between the two traits that would result in a tradeoff between high yield vs. low Zn content, or vice versa. The correlation between these traits measured at the vegetative stage also showed similar weak associations (Supplementary Figure S2). This suggests that selection of genotypes with high Zn content is possible when cowpeas are grown on high soil $\mathrm{P}$. This was confirmed from our analysis which identified several genotypes with high $\mathrm{Zn}$ content and yield under high soil P treatments (Table 3). Some genotypes (IT89KD-288, IAR-48, IT82E-18, IT97K-499-35, UCR779, and DanMisra) had higher grain yield with high Zn content at HP soil environment over other soil P rates (Table 3). Similarly, grain $\mathrm{P}$ and $\mathrm{Zn}(\mathrm{r}=0.1)$ were not significantly correlated at all levels of soil $\mathrm{P}$ treatments, indicating that no strong association exists between these traits.

Table 3. Mean performance of representative genotypes with higher shoot dry weight, grain yield, and grain $\mathrm{Zn}$ content at high soil P fertilization under field environment.

\begin{tabular}{cccccccccc}
\hline Genotypes & $\begin{array}{c}\text { Sdwt } \\
\text {.HP }\end{array}$ & $\begin{array}{c}\text { Sdwt } \\
\text {.MP }\end{array}$ & $\begin{array}{c}\text { Sdwt } \\
\text {.LP }\end{array}$ & $\begin{array}{c}\text { Yield } \\
\text {.HP }\end{array}$ & $\begin{array}{c}\text { Yield } \\
\text {.MP }\end{array}$ & $\begin{array}{c}\text { Yield } \\
\text {.LP }\end{array}$ & $\begin{array}{c}\text { GrainZn } \\
\text {.HP }\end{array}$ & $\begin{array}{c}\text { GrainZn } \\
\text {.MP }\end{array}$ & $\begin{array}{c}\text { GrainZn } \\
\text {.LP }\end{array}$ \\
\hline IT89KD-288 & 98.6 & 33.0 & 19.0 & 1475.0 & 599.2 & 99.9 & 43.7 & 39.2 & 36.2 \\
IAR-48 & 116.5 & 32.0 & 21.9 & 1547.1 & 421.9 & 388.7 & 41.1 & 22.6 & 26.3 \\
IT82E-18 & 90.8 & 49.0 & 21.3 & 1171.1 & 643.9 & 519.2 & 40.7 & 37.2 & 31.7 \\
IT97K-499-35 & 80.3 & 48.0 & 20.2 & 1261.1 & 925.1 & 289.3 & 39.5 & 34.6 & 30.3 \\
UCR779 & 93.6 & 13.0 & 19.5 & 1197.1 & 232.0 & 22.2 & 31.4 & 19.0 & 21.1 \\
DanMisra & 127.6 & 27.0 & 22.1 & 2105.5 & 459.9 & 571.9 & 31.1 & 24.2 & 39.4 \\
\hline
\end{tabular}

$\mathrm{LP}=$ no $\mathrm{P}$ application of $\mathrm{P}_{2} \mathrm{O}_{5}, \mathrm{MP}=10 \mathrm{~kg} \mathrm{P}_{2} \mathrm{O}_{5} \mathrm{ha}^{-1}$, and $\mathrm{HP}=60 \mathrm{~kg} \mathrm{P}_{2} \mathrm{O}_{5}$ ha $^{-1}$ for field evaluation. 


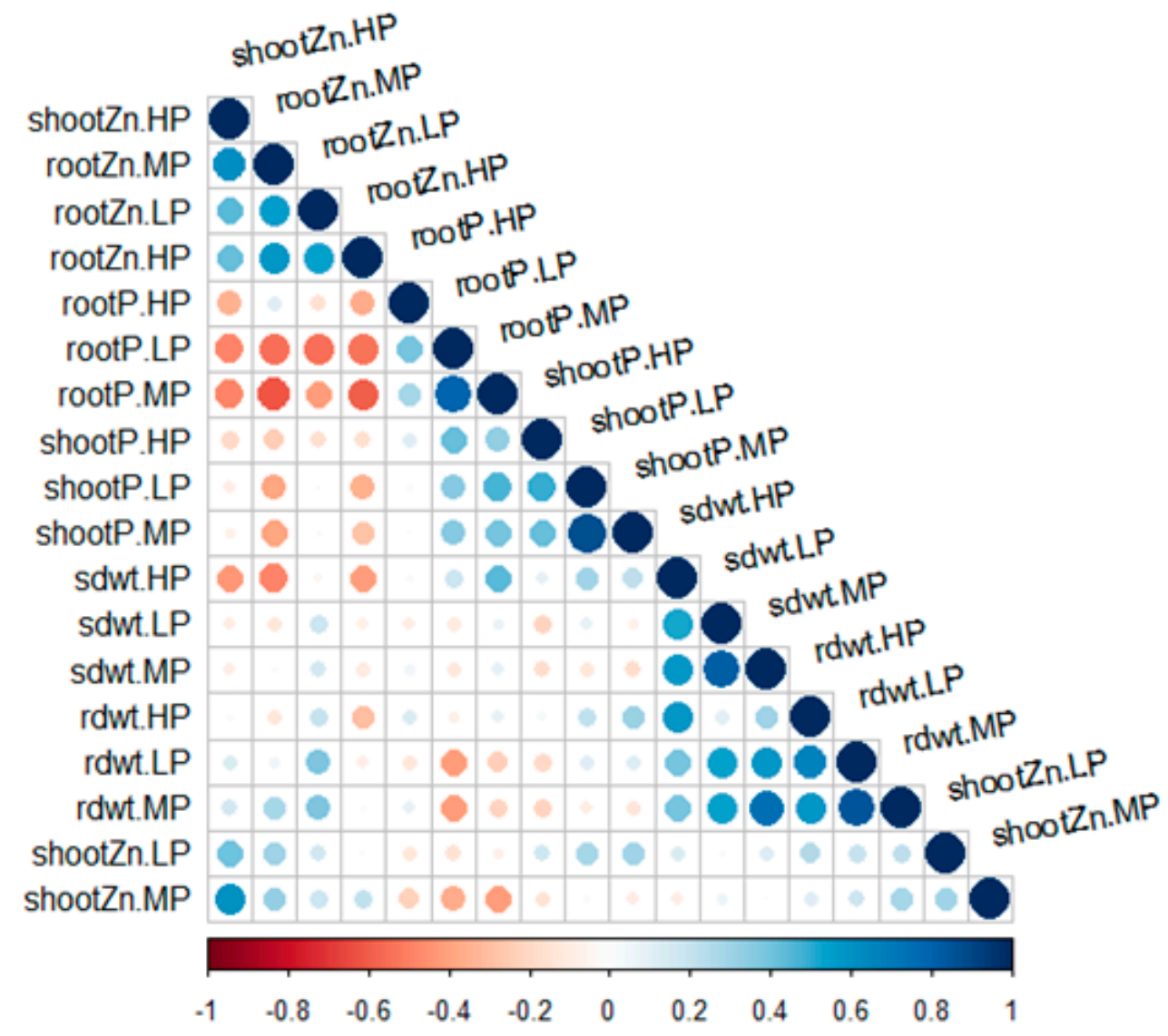

Figure 4. Correlation matrices for traits measured across varying soil phosphorus levels in the screenhouse ( $n=30$ genotypes). Positive and negative associations between given traits are in blue and red, respectively. The color intensity and the size of the circle are proportional to the correlation coefficients. On the $X$-axis of the correlogram, the legend color shows the correlation coefficients and the corresponding colors. $\mathrm{LP}=$ low phosphorus (no-P application), $\mathrm{MP}=$ medium phosphorus $\left(1.5 \mathrm{mg} \mathrm{P} \mathrm{kg}^{-1}\right)$, and $\mathrm{HP}=$ high phosphorus $\left(30 \mathrm{mg} \mathrm{P} \mathrm{kg}^{-1}\right)$. See Table 1 for list and abbreviations of the traits.

Likewise, in the screenhouse experiments, shoot Zn content and shoot dry weight (shoot yield) on HP soil had higher negative association $(\mathrm{r}=-0.4)$ compared to the results in the field, while the shoot $\mathrm{P}$ and $\mathrm{Zn}$ content at all soil $\mathrm{P}$ levels had a weak and insignificant negative relationship $(\mathrm{r}=-0.1-(0.1))$ (Figure 4). Detailed correlation coefficients for these traits in both screenhouse and field experiments are presented respectively in Supplementary Tables S5 and S6. The results indicate that there are suggestive negative relationships between high soil $\mathrm{P}$ and yield (shoot and grain), but they are not strong enough to exclude selection of outstanding genotypes with high yield and Zn content. See Supplementary Figures S3 and S4 for scatter plots that further depict these weak relationships. 


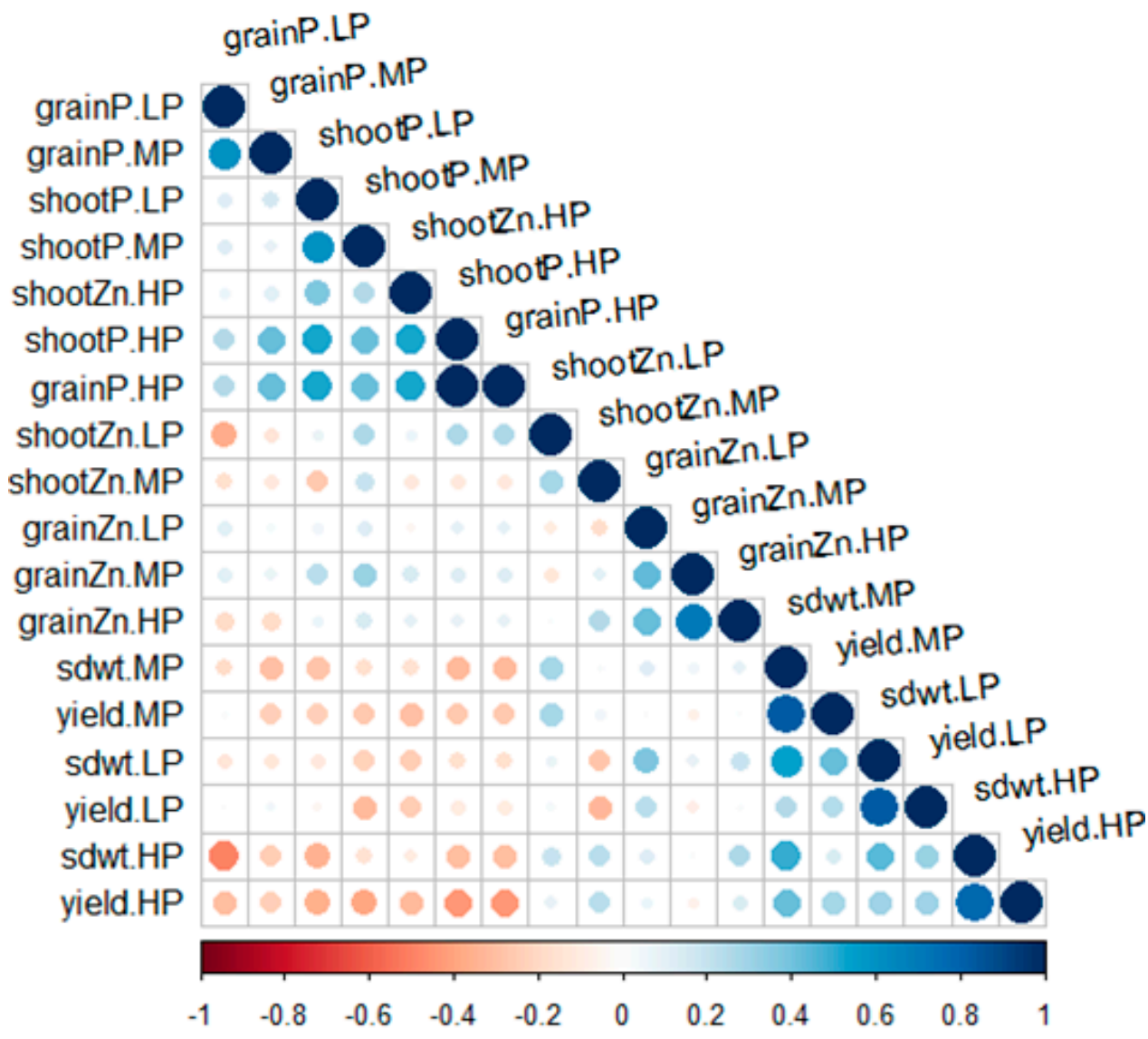

Figure 5. Correlation matrices for traits measured across varying soil phosphorus levels in the field ( $n=30$ genotypes). Positive and negative associations between given traits are in blue and red, respectively. The color intensity and the size of the circle are proportional to the correlation coefficients. On the $X$-axis of the correlogram, the legend color shows the correlation coefficients and the corresponding colors. $\mathrm{LP}=$ no $\mathrm{P}_{2} \mathrm{O}_{5}$ application, $\mathrm{MP}=10 \mathrm{~kg} \mathrm{P}_{2} \mathrm{O}_{5} \mathrm{P}$ ha ${ }^{-1}$, and High $\mathrm{P}=60 \mathrm{~kg}$ $\mathrm{P}_{2} \mathrm{O}_{5} \mathrm{ha}^{-1}$ for $\mathrm{P}$ field evaluation. See Table 1 for list and abbreviations of the traits.

\subsection{Interaction of Genotypes and Phosphorus Rates on Grain Yield and Zinc Content with Biplot Analysis}

The genotype main effect plus genotype by environment (GGE) biplot analysis, where the different soil $P$ rates were considered as distinct environments, revealed the presence of divergence between the genotypes, grain yield, and $\mathrm{Zn}$ content at different soil P conditions. Genotypes 8, 9, 13, 23, and 29 were the top-performing in the HP trials for grain yield, and the angle between their vectors and the HP (environment) vector was less than $90^{\circ}$ (acute angle), while genotypes like 2, 4, 6, 7, 19, and 25 had lower grain yield below the mean and the angle of their vectors appeared to be greater than $90^{\circ}$ (obtuse angle) (Figure 6, see Supplementary Table S1 for names of the genotypes and their corresponding entry numbers). The most stable genotypes across all the environments for the grain yield were $13,16,24$, and 30 , which are nearer to the origin of the biplots of the PC1 vs. PC2, while those genotypes that are farther away from the origin are more sensitive to the varying levels of soil P (Figure 6). 


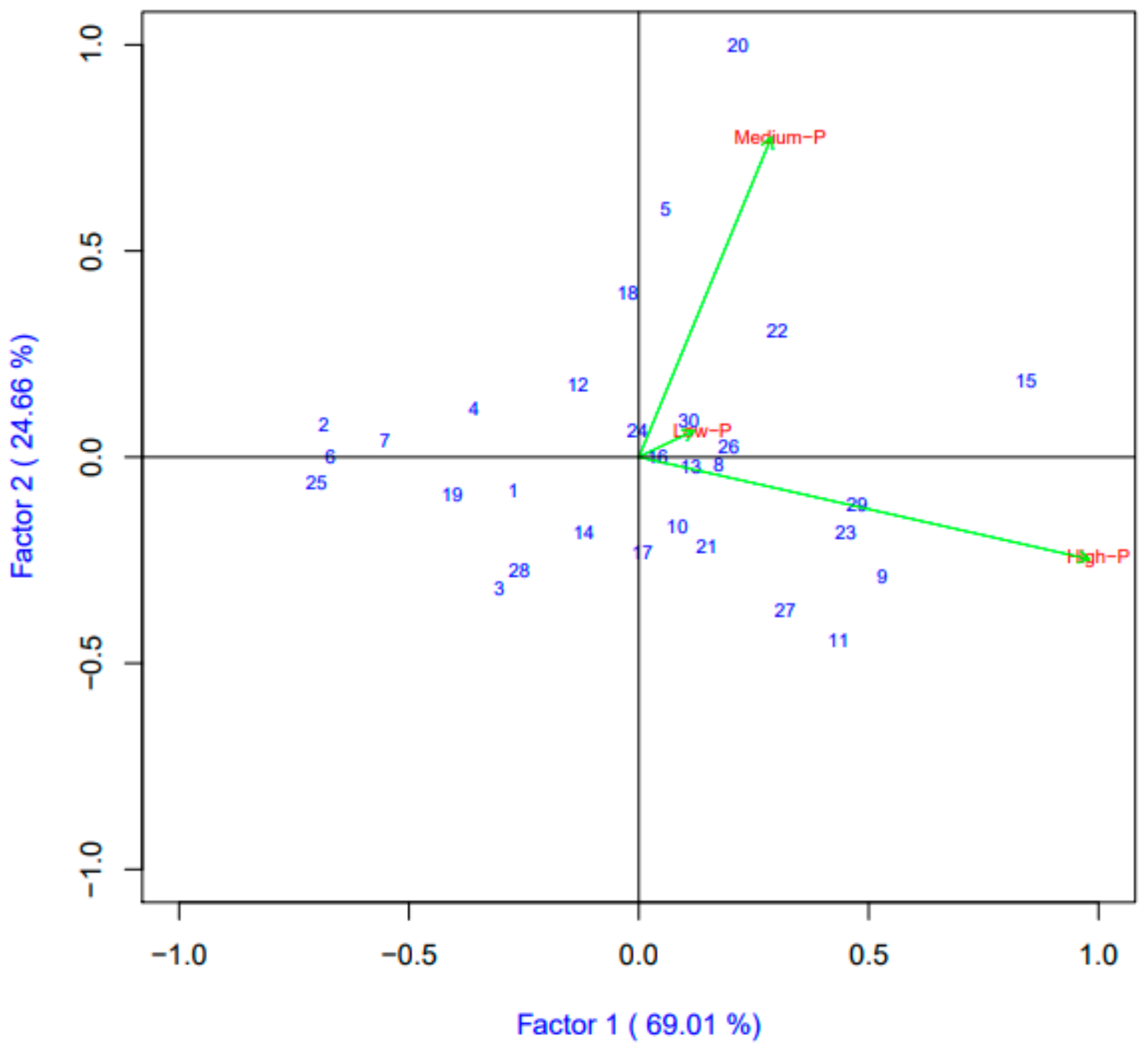

Figure 6. Genotype main effect plus Genotype by Environment (GGE) biplot showing the grain yield of the genotypes at varying soil $\mathrm{P}$ levels. Factors 1 and 2 are the principal component axis. Low- $\mathrm{P}=$ no $\mathrm{P}$ application of $\mathrm{P}_{2} \mathrm{O}_{5}, \mathrm{Medium}-\mathrm{P}=$ $10 \mathrm{~kg} \mathrm{P}_{2} \mathrm{O}_{5} \mathrm{ha}^{-1}$, and High-P $=60 \mathrm{~kg} \mathrm{P}_{2} \mathrm{O}_{5} \mathrm{ha}^{-1}$ for field evaluation.

Genotypes 8, 16, and 22 were the top-performing in the HP trials with high grain $\mathrm{Zn}$ since the angle between their vectors and the $\mathrm{HP}$ vector is less than $90^{\circ}$ (acute angle), while genotypes 2, 4, 5, 14, 17, and 26 had lower grain $\mathrm{Zn}$ below the mean under the HP soil since the angle of their vectors appeared to be greater than $90^{\circ}$ (obtuse angle) (Figure 7). The most stable genotypes across all the P environments for the grain Zn were 3, 21, 22, and 23 because they are nearer to the origin of the biplots of the PC1 vs. PC2, while those genotypes that are farther away from the origin are less stable for grain $\mathrm{Zn}$ content across the $P$ environments, these include genotypes 1, 4, 5, 6, 17, 25, and 29 (Figure 7). The vectors of the $\mathrm{P}$ environments (levels) indicated positive correlations between grain yield and $\mathrm{Zn}$ content because all the vectors of the P levels formed an acute angle. The level of P at HP had the highest discriminating ability, while LP had the least, as shown by the length of their vectors for grain yield, though for the grain Zn content, the LP and MP were more discriminating over the HP (Figures 6 and 7). 


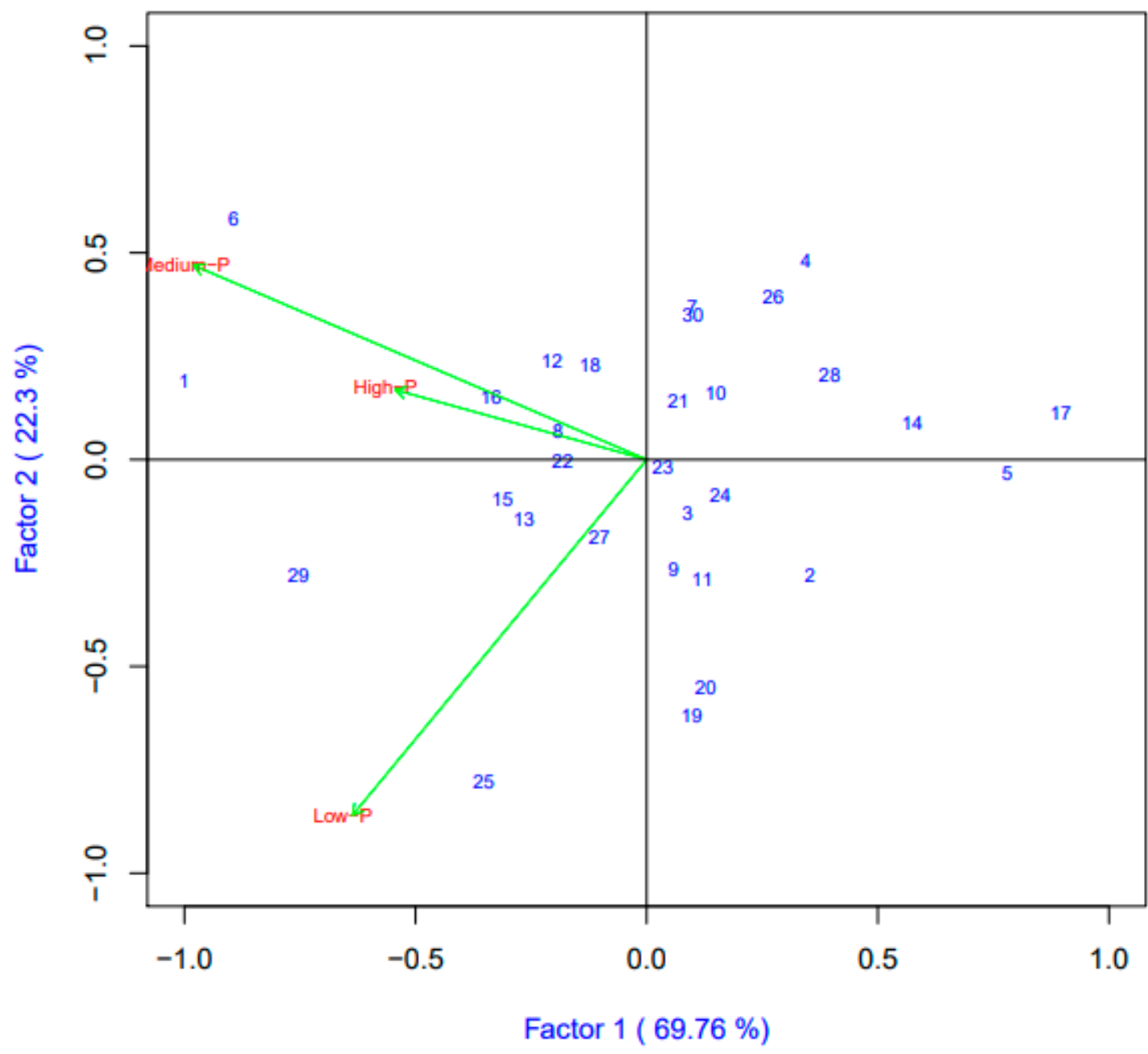

Figure 7. Genotype main effect plus Genotype by Environment (GGE) biplot displaying the genotypes for grain Zn content at varying soil $\mathrm{P}$ levels. Factors 1 and 2 are the principal component axis. Low- $\mathrm{P}=$ no $\mathrm{P}$ application of $\mathrm{P}_{2} \mathrm{O}_{5}, \mathrm{Medium}-\mathrm{P}=$ $10 \mathrm{~kg} \mathrm{P}_{2} \mathrm{O}_{5} \mathrm{ha}^{-1}$, and High-P $=60 \mathrm{~kg} \mathrm{P}_{2} \mathrm{O}_{5} \mathrm{ha}^{-1}$ for field evaluation.

\section{Discussion}

Increased performance of cowpea, as measured by indices of high dry matter yield (shoot, root, and total plant dry weight), increased content of phosphorus (P) in shoots in the screenhouse study using a sand-nutrient solution. High grain yield was observed with an increasing supply of $\mathrm{P}$ in the growth media in the field environment. This corroborates several earlier reports on cowpea's response to the addition of $P$ fertilizer under greenhouse and field conditions [27-30,41,42]. The grain $\mathrm{Zn}$ content of cowpea genotypes evaluated in this study showed no significant differences $(p>0.05)$ across the various $P$ levels applied to the soil. This was further demonstrated by correlation analysis, where grain $\mathrm{Zn}$ content had a non-significant negative association $(r=-0.2, p=0.3)$ with the high rate of $\mathrm{P}$ application compared to the medium and minimal soil $\mathrm{P}$ rates. The negative and non-significant relationship between high soil $\mathrm{P}$ and $\mathrm{Zn}$ content indicates that there is no tradeoff between balancing greater yield and $\mathrm{Zn}$ content. Achieving greater yield with high $\mathrm{P}$ application and desired grain $\mathrm{Zn}$ content are not mutually exclusive. A similar report on two cowpea varieties with differential response to $P$ fertilization showed that high $P$ fertilization, in the absence of Zn application, was associated with Zn deficiency symptoms, even though there was no reduction in the $\mathrm{Zn}$ concentration in the shoots [43]. Other authors have reported that higher rates of $\mathrm{P}$ supplied to cowpea led to a linear increase in grain yield, $\mathrm{P}$ in leaves and seed, but $\mathrm{Zn}$ concentration was reduced in leaves [44] and grains [45]. Increasing P 
supply did not reduce $\mathrm{Zn}$ concentration of plant tissue in Brassica oleracea [46], where more shoot $\mathrm{Zn}$ concentration was seen in one genotype [47]. Earlier observations of increasing $\mathrm{P}$ levels in soil with no reduction in the Zn concentration of non-Zn-supplied plants have been reported in beans and potatoes [48], russet Burbank potato [49], and subterranean clover [50].

The association between plant $\mathrm{P}$ and $\mathrm{Zn}$ concentrations has been a topic of investigation by several researchers. Although, most agree that high $P$ applications could lead to the development of $\mathrm{Zn}$ deficiency symptoms in certain crop plants, but not necessarily cause reduced Zn or P content of plant tissues $[31,47,48]$. In crops or genotypes where the development of $\mathrm{Zn}$ deficiency or reduction in $\mathrm{Zn}$ content because of high soil $\mathrm{P}$ application has been reported, providing optimum $\mathrm{Zn}$ nutrition in the growth medium can be used to remedy the condition. This phenomenon has been described in several publications as $\mathrm{P}$-induced $\mathrm{Zn}$ deficiency [31,48,51]. The inverse relationship between $\mathrm{P}$ and grain $\mathrm{Zn}$ concentrations when a high rate of $P$ is applied without $\mathrm{Zn}$ fertilizers supplied to the growth media has been reported in maize [52,53], wheat [54,55], common beans [56], and numerous other crops [57]. Though, contrary observations have been reported by Loneragan and Webb [31], who provide evidence of a linear relationship between the $\mathrm{Zn}$ and P concentrations in cereals and citrus leaves treated with superphosphate fertilizers. Increased $\mathrm{Zn}$ concentration with high $\mathrm{P}$ application in plants receiving no external supply of $\mathrm{Zn}$ has been documented [31]. However, some authors have opined that such observations may have been due to contamination of the superphosphate used. Nevertheless, in crops where an antagonist relationship exists between high P rates and grain $\mathrm{Zn}$ content, application of $\mathrm{Zn}$ fertilizer/nutrients have been reported to help remedy the situation $[18,31,58-60]$.

In contrast to these results, we observed that a high rate of $\mathrm{P}$ applications had no significant effect on the $\mathrm{Zn}$ content of cowpea genotypes investigated and did not cause the appearance of $\mathrm{Zn}$ deficiency symptoms in cowpea. There are few reports on cowpea addressing the relationship between high $\mathrm{P}$ application and $\mathrm{Zn}$ content of grains or other edible parts [32]. The few reports of the plant $\mathrm{P}-\mathrm{Zn}$ relationship on the crop are sometimes confusing. Oseni [61] reported decreased $\mathrm{Zn}$ content of cowpea plants when $\mathrm{P}$ was applied at high levels in the soil. While a more recent study on the impact of contrasting $P$ rates and constant level of $\mathrm{N}$ fertilizers on iron and $\mathrm{Zn}$ contents of cowpea grains made a contrary observation. Ayeni et al. [32] observed that application of $P$ alone at high rates does not significantly decrease the content of $\mathrm{Zn}$ and Fe on cowpea grains, but a combination of high $\mathrm{P}(60 \mathrm{~kg} / \mathrm{ha})$ and $\mathrm{N}$ was associated with reduced $\mathrm{Zn}$ content of the grains. The authors provided some explanation for this observation, suggesting that the lack of a decrease in Zn content when only high $\mathrm{P}$ rate was applied may be due to applied $\mathrm{P}$ being fixed in certain soil compounds. However, application of N, a known element that could enhance the early establishment of cowpea [62] and uptake of P from soil [63], may be responsible for decreased $\mathrm{Zn}$ content when $\mathrm{N}$ and $\mathrm{P}$ fertilizers were applied at a high level.

Several mechanisms have been proposed to explain plant $\mathrm{P}-\mathrm{Zn}$ interaction in which a decrease in $\mathrm{Zn}$ content is observed in certain crops or genotypes when $\mathrm{P}$ application is at the highest level in the growth media. One of the mechanisms responsible for P-induced $\mathrm{Zn}$ reduction in plant tissues includes the following: First, increasing P supply to the growth medium stimulates the growth of crop plants sufficiently to dilute the concentration of $\mathrm{Zn}$ in plant tissues to levels that could induce a decrease in $\mathrm{Zn}$ availability. Second, the high P supply could suppress either absorption of $\mathrm{Zn}$ by roots or translocation of $\mathrm{Zn}$ from roots to shoots $[31,57,64,65]$. The lower value of grain $\mathrm{Zn}$ content in some genotypes at high soil P may be due to decreased diffusion of $\mathrm{Zn}$ in the soil colloids [57,65]. Another explanation for the high $\mathrm{P}-\mathrm{Zn}$ reduced bioavailability is that, when both $\mathrm{P}$ and $\mathrm{Zn}$ are limited in soil, application of high $P$ rates tends to promote plant growth and this could cause dilution in tissue $\mathrm{Zn}$, which may further lead to reduced availability of $\mathrm{Zn}$ in plant tissues [31]. Such observations have led to the belief that an imbalance in the ratios of $\mathrm{P}-\mathrm{Zn}$ in the growth environment may be responsible for the reduced $\mathrm{Zn}$ content observed in some crops/genotypes when P is applied at a high rate [43]. Some authors have also 
observed the highest grain $\mathrm{Zn}$ concentration on fields where mineral N, P fertilizers, and organic nutrient sources were applied [20].

In the present study, we observed that the "so-called" P-induced Zn reduction phenomenon may be genotype-dependent because the relationship between the increased yield due to high $\mathrm{P}$ application and $\mathrm{Zn}$ content revealed an insignificant negative association. Earlier investigations have supported this. Susceptibility to P-induced Zn deficiency was attributed to genetic differences and soil conditions in cowpea [20,43] and navy beans [51], where varieties had varying efficiency to absorb and use nutrient constituents of the soil.

Various approaches have been used to achieve greater grain yield and $\mathrm{Zn}$ content in soils with higher $\mathrm{P}$ application. These include the application of $\mathrm{Zn}$ fertilizers either as a foliar spray [18] or applied directly to the soil [20,53,58], improved agronomic practices such as integrated soil fertility management and intercropping, in which cereals can increase $\mathrm{Zn}$ bioavailability of the soil and benefit the companion legumes [20,66], adopting multiple strategies such as dietary diversification [20], which could mean supplementing cowpea meal with high micronutrient-rich crops like common beans, a legume also rich in $\mathrm{Zn}$ content $[17,19]$, and cultivation of varieties with inherently high $\mathrm{Zn}$ concentration at any soil $P$ rates. Other researchers [32] have recommended application of medium $P$ rates such as $40 \mathrm{~kg} \mathrm{P}_{2} \mathrm{O}_{5} /$ ha even without application of $\mathrm{Zn}$ fertilizer to obtain high yield and $\mathrm{Zn}$ content in the grains $[30,44,61]$. Application of $\mathrm{Zn}$-containing fertilizers has been observed elsewhere to increase cowpea's grain Zn content and yield under integrated soil fertility management [20].

Ayeni et al. [32] observed that some cowpea genotypes had a high content of $\mathrm{Zn}$ at all levels of $\mathrm{P}$, a finding similar to our observation in this study where certain genotypes such as IT82E-18, UCR779, CB46, and IT97K-556-6 had increased grain Zn content with increasing supply of $P$ in the growth environment. This was confirmed by the GGE biplots that displayed genotypes, such as 16 (IT89KD-288), 8 (Danila), and 22 (SAMPEA-9), with high grain Zn content under high soil P fertilization, while genotypes such as 3 (58-77), 21 (SAMPEA-17), 22 (SAMPEA-9), and 23 (Sanzi) had stable grain $\mathrm{Zn}$ across all P levels. In this study, we identified 3 very stable high-grain $Z$ n-containing genotypes at high soil $\mathrm{P}$ rate and 4 high-grain $\mathrm{Zn}$ genotypes across all the $\mathrm{P}$ levels based on site regression analysis (SREG) biplot analysis [40]. Also, genotypes with high grain yield at all P levels were identified. The use of GGE biplot analysis enabled us to visualize the genotypes and their association with the different $P$ rates (serving as environments) using biplots, which shows genotypes that are high-performing for grain yield and grain $\mathrm{Zn}$ content at each P rate and those that are most stable across all $P$ levels $[32,67]$. The genotypes identified with high grain $\mathrm{Zn}$ at a high $\mathrm{P}$ level should be tested in more locations to further substantiate this finding and make possible recommendations for release to farmers as high $\mathrm{Zn}$ varieties.

\section{Conclusions}

There was wide variation for the P concentration and $\mathrm{Zn}$ content of cowpea genotypes investigated. Increasing P fertilization leads to a significant increase in yield and concentration of $\mathrm{P}$ in the shoots of the cowpea materials assessed. We conclude that since no significant relationship between increased $\mathrm{P}$ fertilization and grain $\mathrm{Zn}$ content was observed and high $P$ fertilization is related to greater yield, there is no reason to not fertilize with $\mathrm{P}$ at high levels. Increased grain yield under high $\mathrm{P}$ supply can be achieved without sacrificing desired Zn content, especially if genotypes such as IT89KD-288, IAR-48, IT97K499-35, UCR779, CB46, IT97K-556-6, IT82E-18, and DanMisra, that do not show a negative impact of decreased grain $\mathrm{Zn}$ content at high rates of $\mathrm{P}$, are cultivated. The high-grain $\mathrm{Zn}$ genotypes at high $P$ fertilization can be used as parents in conventional or molecular plant breeding pipelines for further improvement of grain $\mathrm{Zn}$ content in cowpea varieties that are popularly grown in major producing areas.

Supplementary Materials: The following are available online at https: / www.mdpi.com/article/ 10.3390/agronomy11040802/s1, Figure S1: Phenotypic distribution of traits measured in the field experiment at the vegetative stage under varying soil phosphorus levels. Box plot displays the 
median of each group bounded by the first and third quartile, with 1_LP = no-P application, 2_MP $=10 \mathrm{~kg} \mathrm{P}_{2} \mathrm{O}_{5} \mathrm{ha}^{-1} \& 3 \_\mathrm{HP}=60 \mathrm{~kg} \mathrm{P}_{2} \mathrm{O}_{5} \mathrm{ha}^{-1}$. Figure S2: Correlation matrices for traits measured across varying soil phosphorus concentrations in the field experiment at the vegetative stage ( $n=30$ genotypes). See Table 1 for list and abbreviations of the traits. Positive and negative associations between given traits are in blue and red, respectively. The color intensity and the size of the circle are proportional to the correlation coefficients. On the $X$-axis of the correlogram, the legend color shows the correlation coefficients and the corresponding colors. Figure S3: Scatterplot showing weak correlations between pairs of traits from the field evaluation (a) Shoot dry weight (g) and shoot $\mathrm{Zn}$ content (ppm) of high phosphorus treatment, $\mathrm{R}=-0.10 ; \mathrm{P}=0.58$, (b) Soil available phosphorus (mg/kg) and grain Zn content (ppm), $\mathrm{R}=-0.20, \mathrm{P}=0.29$, (c) Grain yield (kg/ha) and grain $\mathrm{Zn}$ content (ppm), $\mathrm{R}=0.13, \mathrm{P}=0.47$, (d) Grain phosphorus (mg/kg) and grain $\mathrm{Zn}$ content (ppm), $\mathrm{R}=0.02, \mathrm{P}=0.92$. Each point represents an average of a genotype. Figure S4: Scatterplot showing weak correlations between pairs of traits from the screenhouse evaluation (a) Shoot dry weight $(\mathrm{g})$ and shoot $\mathrm{Zn}$ content $(\mathrm{ppm})$ of high phosphorus treatment, $\mathrm{R}=-0.43 ; \mathrm{P}=0.02$, (b) Shoot phosphorus $(\mathrm{mg} / \mathrm{kg}$ ) and shoot $\mathrm{Zn}$ content $(\mathrm{ppm})$ of high phosphorus treatment, $\mathrm{R}=-0.20$, $\mathrm{P}=0.29$, (c) Root dry weight (g) and root $\mathrm{Zn}$ content (ppm) of high phosphorus treatment, $\mathrm{R}=-0.30$, $\mathrm{P}=0.11$, (d) Root phosphorus ( $\mathrm{mg} / \mathrm{kg}$ ) and root $\mathrm{Zn}$ content $(\mathrm{ppm})$ of high phosphorus treatment, $\mathrm{R}=0.37, \mathrm{P}=0.04$. Each point represents an average of a genotype. Table S1: List of cowpea genotypes used and their origin/source, Table S2: Formulae used for computation of relative reduction (\%), phosphorus concentration, and zinc content of samples, Table S3: Means of genotypes for shoot parameters measured in the screenhouse experiment under three soil phosphorus concentrations, Table S4: Means of cowpea genotypes for shoot parameters measured in the field experiment under three soil phosphorus concentrations, Table S5: Trait correlations between dry biomass yield, P and $\mathrm{Zn}$ content of shoot and root of genotypes evaluated in the screenhouse under varying soil P rates, Table S6: Trait correlations between grain yield, $\mathrm{P}$ and $\mathrm{Zn}$ content of shoot and grain of genotypes evaluated in the field under varying soil $P$ rates.

Author Contributions: Conceptualization, S.B.M., D.K.D., M.F.I., P.B.T., and V.G.; formal analysis, investigation, writing-original draft preparation, S.B.M.; writing-review and editing, S.B.M., D.K.D., A.Y., M.L.U., M.F.I., P.B.T., and V.G.; supervision, D.K.D., M.F.I., P.B.T., and V.G.; funding acquisition, S.B.M. All authors have read and agreed to the published version of the manuscript.

Funding: This research was partly funded by the Bill and Melinda Gates Foundation through the Program for Emerging Agricultural Research Leaders (PEARL II) to the Ahmadu Bello University, Nigeria, grant number "OPP1131397/INV-009560", and The APC was funded by (OPP1131397/ INV-009560).

Institutional Review Board Statement: Not applicable.

Informed Consent Statement: Not applicable.

Data Availability Statement: The data presented in this study are available within the article and as Supplementary Material.

Acknowledgments: The present study was part of the PhD thesis of the first author. The first author acknowledges the West Africa Agricultural Productivity Programme (WAAPP-Nigeria, a World Bank Supported Intervention) for funding part of his PhD work. The authors are thankful to the team of Technicians at the Cowpea Breeding Unit of the Institute for Agricultural Research Ahmadu Bello University, Nigeria, for their assistance in conducting the experiments. The authors are grateful to James D. Burridge and Mustafa Jibirn Ojonuba for their insightful comments.

Conflicts of Interest: The authors declare no conflict of interest.

\section{References}

1. White, P.J.; Broadley, M.R. Biofortification of crops with seven mineral elements often lacking in human diets - iron, zinc, copper, calcium, magnesium, selenium and iodine. New Phytol. 2009, 182, 49-84. [CrossRef]

2. Philipo, M.; Ndakidemi, P.A.; Mbega, E.R. Environmental and genotypes influence on seed iron and zinc levels of landraces and improved varieties of common bean (Phaseolus vulgaris L.) in Tanzania. Ecol. Genet. Genom. 2020, 15, 100056. [CrossRef]

3. Hambidge, M. Human Zinc Deficiency. J. Nutr. 2000, 130, 1344S-1349S. [CrossRef]

4. Brown, K.H.; Wuehler, S.E.; Peerson, J.M. The importance of zinc in human nutrition and estimation of the global prevalence of zinc defi ciency. Food Nutr. Bull. 2001, 22, 13. [CrossRef] 
5. Deshpande, J.D.; Joshi, M.M.; Giri, P.A. Zinc in Human Nutrition And Health 1. Int. J. Med. Sci. Public Health 2013, 2. [CrossRef]

6. Abate, T.; Alene, A.D.; Bergvinson, D.; Shiferaw, B.; Silim, S.; Orr, A.; Asfaw, S. Tropical Grain Legumes in Africa and South Asia: Knowledge and Opportunities; International Crops Research Institute for the Semi-Arid Tropics; ICRISAT-Nairobi: Nairobi City, Kenya, 2011.

7. Boukar, O.; Belko, N.; Chamarthi, S.; Togola, A.; Batieno, J.; Owusu, E.; Haruna, M.; Diallo, S.; Umar, M.L.; Olufajo, O.; et al. Cowpea (Vigna unguiculata): Genetics, genomics and breeding. Plant Breed. 2018, 1-10. [CrossRef]

8. Langyintuo, A.S.; Lowenberg-Deboer, J.; Faye, M.; Lambert, D.; Ibro, G.; Moussa, B.; Kergna, A.; Kushwaha, S.; Musa, S.; Ntoukam, G. Cowpea supply and demand in West and Central Africa. Field Crop. Res. 2003, 82, 215-231. [CrossRef]

9. Phillips, R.D.; Mcwatters, K.H.; Chinnan, M.S.; Hung, Y.-C.; Beuchat, L.R.; Sefa-Dedeh, S.; Sakyi-Dawson, E.; Ngoddy, P.; Nnanyelugo, D.; Enwere, J.; et al. Utilization of cowpeas for human food. Field Crop. Res. 2003, 82, 193-213. [CrossRef]

10. Samireddypalle, A.; Boukar, O.; Grings, E.; Fatokun, C.A.; Kodukula, P.; Devulapalli, R.; Okike, I.; Blümmel, M. Cowpea and Groundnut Haulms Fodder Trading and Its Lessons for Multidimensional Cowpea Improvement for Mixed Crop Livestock Systems in West Africa. Front. Plant Sci. 2017, 08, 30. [CrossRef]

11. Snapp, S.; Rahmanian, M.; Batello, C. Pulse Crops for Sustainable Farms in Sub-Saharan Africa; FAO: Rome, Italy, 2018.

12. Horn, L.; Shimelis, H.; Laing, M. Participatory appraisal of production constraints, preferred traits and farming system of cowpea in the northern Namibia: Implications for breeding. Legum. Res. 2014, 38, 691-700. [CrossRef]

13. Magani, I.E.; Kuchinda, C. Effect of phosphorus fertilizer on growth, yield and crude protein content of cowpea (Vigna unguiculata [L.] Walp) in Nigeria. J. Appl. Biosci. 2009, 23, 1387-1393.

14. Mohammed, S.B.; Mohammad, I.F.; Pangirayi, T.B.; Vernon, G.; Dzidzienyo, D.K.; Umar, M.L.; Umar, S. Farmers' knowledge, perception, and use of phosphorus fertilization for cowpea production in Northern Guinea Savannah of Nigeria. Heliyon 2020, 6 . [CrossRef]

15. Genc, Y.; Humphries, J.M.; Lyons, G.H.; Graham, R.D. Exploiting genotypic variation in plant nutrient accumulation to alleviate micronutrient deficiency in populations. J. Trace Elem. Med. Biol. 2005, 18, 319-324. [CrossRef] [PubMed]

16. Gonçalves, A.; Goufo, P.; Barros, A.; Domínguez-Perles, R.; Trindade, H.; Rosa, E.A.S.; Ferreira, L.; Rodrigues, M. Cowpea (Vigna unguiculata L. Walp), a renewed multipurpose crop for a more sustainable agri-food system: Nutritional advantages and constraints: Nutritional aptitude of cowpea. J. Sci. Food Agric. 2016, 96, 2941-2951. [CrossRef] [PubMed]

17. Cichy, K.A.; Caldas, G.V.; Snapp, S.S.; Blair, M.W. QTL Analysis of Seed Iron, Zinc, and Phosphorus Levels in an Andean Bean Population. Crop Sci. 2009, 49. [CrossRef]

18. Zhang, Y.-Q.; Deng, Y.; Chen, R.-Y.; Cui, Z.-L.; Chen, X.-P.; Yost, R.; Zhang, F.-S.; Zou, C.-Q. The reduction in zinc concentration of wheat grain upon increased phosphorus-fertilization and its mitigation by foliar zinc application. Plant Soil 2012, 361, 143-152. [CrossRef]

19. Blair, M.W.; Medina, J.I.; Astudillo, C.; Rengifo, J.; Beebe, S.E.; Machado, G.; Graham, R. QTL for seed iron and zinc concentration and content in a Mesoamerican common bean (Phaseolus vulgaris L.) population. Theor. Appl. Genet. 2010, 121, 1059-1070. [CrossRef]

20. Manzeke, M.G.; Mtambanengwe, F.; Nezomba, H.; Watts, M.J.; Broadley, M.R.; Mapfumo, P. Zinc fertilization increases productivity and grain nutritional quality of cowpea (Vigna unguiculata [L.] Walp.) under integrated soil fertility management. Field Crop. Res. 2017, 213, 231-244. [CrossRef]

21. White, P.J.; Broadley, M.R. Biofortifying crops with essential mineral elements. Trends Plant Sci. 2005, 10, 586-593. [CrossRef]

22. Gaddameedi, A.; Ravikiran, K.T.; Mohammed, R.; Phuke, R.M.; Sadaiah, K.; Kavi Kishor, P.B.; Ashok Kumar, A. Inheritance studies on grain iron and zinc concentration and agronomic traits in sorghum [Sorghum bicolor (L.) Moench]. J. Cereal Sci. 2018, 83, 252-258. [CrossRef]

23. ICRISAT. Enhancing Cowpea Productivity and Production in Drought-Prone Areas of Sub-Saharan Africa; ICRISAT: Patancheruvu, India, 2017.

24. Olufajo, O.O.; Singh, B.B. Advances in cowpea cropping systems research. In Challenges and Opportunities for Enhancing Sustainable Cowpea Production; Fatokun, C.A., Tarawali, S.A., Singh, B.B., Kormawa, P.M., Tamò, M., Eds.; International Institute of Tropical Agriculture, IITA: Ibadan, Nigeria, 2002; pp. 267-277.

25. Simpson, R.J.; Oberson, A.; Culvenor, R.A.; Ryan, M.H.; Veneklaas, E.J.; Lambers, H.; Lynch, J.P.; Ryan, P.R.; Delhaize, E.; Smith, F.A.; et al. Strategies and agronomic interventions to improve the phosphorus-use efficiency of farming systems. Plant Soil 2011, 349, 89-120. [CrossRef]

26. Oladiran, O.; Olajire, F.; Abaidoo, R.C.; Nnenna, I. Phosphorus Response Efficiency in Cowpea Genotypes. J. Agric. Sci. 2012, 4, 81-90. [CrossRef]

27. Sanginga, N.; Lyasse, O.; Singh, B.B. Phosphorus use efficiency and nitrogen balance of cowpea breeding lines in a low P soil of the derived savanna zone in West Africa. Plant Soil 2000, 220, 119-128. [CrossRef]

28. Gyan-Ansah, S.; Adu-Dapaah, H.; Kumaga, F.; Gracen, V.; Nartey, F.K.K. Evaluation of cowpea (Vigna unguiculata L. Walp.) genotypes for phosphorus use efficiency. Acta Hortic. 2016, 373-380. [CrossRef]

29. Adusei, G.; Gaiser, T.; Boukar, O.; Fatokun, C. Growth and yield responses of cowpea genotypes to soluble and rock P fertilizers on acid, highly weathered soil from humid tropical West Africa. Int. J. Biol. Chem. Sci. 2016, 10, 1493-1507. [CrossRef]

30. Saidou, A.K.; Singh, B.B.; Abaidoo, R.C.; Iwuafor, E.N.O.; Sanginga, N. Response of cowpea lines to low Phosphorus tolerance and response to external application of P. Afr. J. Microbiol. Res. 2012, 6, 5479-5485. [CrossRef] 
31. Loneragan, J.F.; Webb, M.J. Interactions Between Zinc and Other Nutrients Affecting the Growth of Plants. In Zinc in Soils and Plants; Robson, A.D., Ed.; Springer Netherlands: Dordrecht, The Netherlands, 1993; pp. 119-134.

32. Ayeni, D.F.; Ikwebe, J.; Onyezili, F.N. Iron and zinc levels in Vigna unguiculata (L.) Walp under varying phosphorus and fixed nitrogen treatment conditions. Food Energy Secur. 2018, 7, e00141. [CrossRef]

33. Santos, C.A.F.; Boiteux, L.S. Breeding biofortifed cowpea lines for semi-arid tropical areas by combining higher seed protein and mineral levels. Genet. Mol. Res. 2013, 12, 6782-6789. [CrossRef] [PubMed]

34. Ashok Kumar, A.; Reddy, B.V.S.; Ramaiah, B.; Sahrawat, K.L.; Pfeiffer, W.H. Gene effects and heterosis for grain iron and zinc concentration in sorghum [Sorghum bicolor (L.) Moench]. Field Crop. Res. 2013, 146, 86-95. [CrossRef]

35. Huynh, B.-L.; Ehlers, J.D.; Close, T.J.; Cis, N.; Drabo, I.; Boukar, O.; Lucas, M.R.; Wanamaker, S.; Pottorff, M.; Roberts, P.A. Enabling Tools for Modern Breeding of Cowpea for Biotic Stress Resistance. In Translational Genomics for Crop Breeding, Volume I: Biotic Stress; Varshney, R.K., Tuberosa, R., Eds.; John Wiley \& Sons, Inc.: Hoboken, NJ, USA, 2013; pp. $183-199$.

36. Boukar, O.; Fatokun, C.A.; Huynh, B.-L.; Roberts, P.A.; Close, T.J. Genomic Tools in Cowpea Breeding Programs: Status and Perspectives. Front. Plant Sci. 2016, 7, 1-13. [CrossRef]

37. Muñoz-Amatriaín, M.; Mirebrahim, H.; Xu, P.; Wanamaker, S.I.; Luo, M.C.; Alhakami, H.; Alpert, M.; Atokple, I.; Batieno, B.J.; Boukar, O.; et al. Genome resources for climate-resilient cowpea, an essential crop for food security. Plant J. 2017, 89, 1042-1054. [CrossRef]

38. Bationo, A.; Ntare, B.R.; Tarawali, S.A.; Tabo, R. Soil fertility management and cowpea production in the semiarid tropics. In Challenges and Opportunities for Enhancing Sustainable Cowpea Production; Fatokun, C.A., Tarawali, S.A., Singh, B.B., Kormawa, P.M., Tamo, M., Eds.; International Institute of Tropical Agriculture, IITA: Ibadan, Nigeria, 2002; pp. 301-318.

39. Rothe, C.J. Breeding for Tolerance of Cowpea to Low Phosphorus Soil Conditions through Physiological and Genetic Studies. Ph.D. Thesis, Texas A\&M University, College Station, TX, USA, 2014.

40. Pacheco, Á.; Vargas, M.; Alvarado, G.; Rodríguez, F.; Crossa, J.; Burgueño, J. GEA-R (Genotype x Environment Analysis with R for Windows); Version 4.1; CIMMYT: Mexico City, Mexico, 2015.

41. Kolawole, G.O.; Tian, G.; Singh, B.B. Differential response of cowpea lines to aluminum and phosphorus application. J. Plant Nutr. 2008, 23, 731-740. [CrossRef]

42. Krasilnikoff, G.; Gahoonia, T.; Nielsen, N.E. Variation in phosphorus uptake efficiency by genotypes of cowpea (Vigna unguiculata) due to differences in root and root hair length and induced rhizosphere processes. Plant Soil 2003, 251, 83-91. [CrossRef]

43. Safaya, N.M.; Singh, B. Differential susceptibility of two varieties of cowpea (Vigna unguiculata (L) Walp) to phosphorus-induced zinc deficiency. Plant Soil 1977, 48, 279-290. [CrossRef]

44. Benvindo, R.N.; Prado, R.D.M.; Nóbrega, J.C.A.; Flores, R.A. Phosphorus Fertilization on the Nutrition and Yield of Cowpea Grown in an Arenosols. J. Agric. Environ. Sci 2014, 14, 434-439. [CrossRef]

45. Nyoki, D.; Ndakidemi, P.A. Influence of Bradyrhizobium japonicum and Phosphorus on Micronutrient Uptake in Cowpea. A Case Study of Zinc (Zn), Iron (Fe), Copper (Cu) and Manganese (Mn). Am. J. Plant Sci. 2014, 5, 427-435. [CrossRef]

46. Pongrac, P.; Fischer, S.; Thompson, J.A.; Wright, G.; White, P.J. Early Responses of Brassica oleracea Roots to Zinc Supply Under Sufficient and Sub-Optimal Phosphorus Supply. Front. Plant Sci. 2020, 10. [CrossRef] [PubMed]

47. Pongrac, P.; Castillo-Michel, H.; Reyes-Herrera, J.; Hancock, R.D.; Fischer, S.; Kelemen, M.; Thompson, J.A.; Wright, G.; Likar, M.; Broadley, M.R.; et al. Effect of phosphorus supply on root traits of two Brassica oleracea L. genotypes. BMC Plant Biol. 2020, 20, 368. [CrossRef]

48. Boawn, L.C.; Brown, J.C. Further Evidence for a P-Zn Imbalance in Plants. Soil Sci. Soc. Am. J. 1968, 32, 94-97. [CrossRef]

49. Boawn, L.C.; Leggett, G.E. Phosphorus and Zinc Concentrations in Russet Burbank Potato Tissues in Relation to Development of Zinc Deficiency Symptoms. Soil Sci. Soc. Am. J. 1964, 28, 229-232. [CrossRef]

50. Millikan, C. Effects of different levels of zinc and phosphorus on the growth of subterranean clover (Trifolium subterraneum L.). Aust. J. Agric. Res. 1963, 14, 180-205. [CrossRef]

51. Ambler, J.E.; Brown, J.C. Cause of Differential Susceptibility to Zinc Deficiency in Two Varieties of Navy Beans (Phaseolus vulgaris L.). Agron. J. 1969, 61, 41-43. [CrossRef]

52. Bogdanovic, D.; Ubavic, M.; Cuvardic, M. Effect of phosphorus fertilization on Zn and Cd contents in soil and corn plants. Nutr. Cycl. Agroecosyst. 1999, 54, 49-56. [CrossRef]

53. Imran, M.; Rehim, A.; Sarwar, N.; Hussain, S. Zinc bioavailability in maize grains in response of phosphorous-zinc interaction. J. Plant Nutr. Soil Sci. 2016, 179, 60-66. [CrossRef]

54. Ova, E.A.; Kutman, U.B.; Ozturk, L.; Cakmak, I. High phosphorus supply reduced zinc concentration of wheat in native soil but not in autoclaved soil or nutrient solution. Plant Soil 2015, 393, 147-162. [CrossRef]

55. Ryan, M.H.; McInerney, J.K.; Record, I.R.; Angus, J.F. Zinc bioavailability in wheat grain in relation to phosphorus fertiliser, crop sequence and mycorrhizal fungi. J. Sci. Food Agric. 2008, 88, 1208-1216. [CrossRef]

56. Singh, J.P.; Karamanos, R.E.; Stewart, J.W.B. The mechanism of phosphorus-induced zinc deficiency in bean (Phaseolus vulgaris L.). Can. J. Soil Sci. 1988, 68, 345-358. [CrossRef]

57. Fageria, V.D. Nutrient interactions in crop plants. J. Plant Nutr. 2001, 24, 1269-1290. [CrossRef]

58. Liu, D.-Y.; Zhang, W.; Liu, Y.-M.; Chen, X.-P.; Zou, C.-Q. Soil Application of Zinc Fertilizer Increases Maize Yield by Enhancing the Kernel Number and Kernel Weight of Inferior Grains. Front. Plant Sci. 2020, 11, 188. [CrossRef] 
59. Rose, T.J.; Impa, S.M.; Rose, M.T.; Pariasca-Tanaka, J.; Mori, A.; Heuer, S.; Johnson-Beebout, S.E.; Wissuwa, M. Enhancing phosphorus and zinc acquisition efficiency in rice: A critical review of root traits and their potential utility in rice breeding. Ann. Bot. 2013, 112, 331-345. [CrossRef]

60. Qaswar, M.; Hussain, S.; Rengel, Z. Zinc fertilisation increases grain zinc and reduces grain lead and cadmium concentrations more in zinc-biofortified than standard wheat cultivar. Sci. Total Environ. 2017, 605-606, 454-460. [CrossRef]

61. Oseni, T.O. Growth and zinc uptake of sorghum and cowpea in response to phosphorus and zinc fertilization. World J. Agric. Sci. 2009, 5, 670-674.

62. Abdul Rahman, N.; Larbi, A.; Kotu, B.; Marthy Tetteh, F.; Hoeschle-Zeledon, I. Does Nitrogen Matter for Legumes? Starter Nitrogen Effects on Biological and Economic Benefits of Cowpea (Vigna unguiculata L.) in Guinea and Sudan Savanna of West Africa. Agronomy 2018, 8, 120. [CrossRef]

63. Ngwene, B.; George, E.; Claussen, W.; Neumann, E. Phosphorus uptake by cowpea plants from sparingly available or soluble sources as affected by nitrogen form and arbuscular-mycorrhiza-fungal inoculation. J. Plant Nutr. Soil Sci. 2010, 173, 353-359. [CrossRef]

64. Nishigaki, T.; Tsujimoto, Y.; Rinasoa, S.; Rakotoson, T.; Andriamananjara, A.; Razafimbelo, T. Phosphorus uptake of rice plants is affected by phosphorus forms and physicochemical properties of tropical weathered soils. Plant Soil 2019, 435, 27-38. [CrossRef]

65. Amin, S.; Che, F.I.; Hanafi, M.M.; Hamed, Z.; Zaharah, A.R. Phosphorus and Zinc Uptake and Their Interaction Effect on Dry Matter and Chlorophyll Content of Sweet Corn (Zea mays var. Saccharat). J. Agron. 2013, 12, 187-192.

66. Xue, Y.; Xia, H.; Christie, P.; Zhang, Z.; Li, L.; Tang, C. Crop acquisition of phosphorus, iron and zinc from soil in cereal/legume intercropping systems: A critical review. Ann. Bot. 2016, 117, 363-377. [CrossRef]

67. Ukalski, K.; Klisz, M. Application of GGE biplot graphs in multi-environment trials on selection of forest trees. Folia For. Pol. Ser. A 2016, 58, 228-239. [CrossRef] 